\title{
RESPON SISWA TERHADAP LKS BERBASIS INKUIRI TERBIMBING PADA SUBMATERI SISTEM PERNAPASAN MANUSIA KELAS XI
}

\author{
Tesa Manisa ${ }^{1}$, Eka Aryati $^{2}$, Reni Marlina ${ }^{3}$ \\ 1,2,3Pendidikan Biologi FKIP Universitas Tanjungpura \\ Jalan Prof. Dr. Hadari Nawawi Pontianak \\ ${ }^{1}$ e-mail: tesamanisa68@gmail.com
}

\begin{abstract}
Abstrak
Penelitian bertujuan untuk mengetahui respon siswa terhadap Lembar Kerja Siswa (LKS) berbasis inkuiri terbimbing pada submateri Sistem Pernapasan Manusia. Metode penelitian adalah penelitian deskriptif dengan subjek penelitian siswa kelas XI MIA 4 SMA Negeri 1 Pontianak tahun ajaran 2016/2017 berjumlah 28 siswa. Penelitian merupakan penelitian lanjutan dari penelitian pengembangan yang telah dilakukan oleh peneliti sebelumnya. Teknik pengumpulan data menggunakan angket respon siswa. Angket yang digunakan merupakan angket tertutup menggunakan skala likert dengan empat skala penilaian. Terdapat tiga dimensi respon yang akan dilihat yakni dimensi kognitif, afektif, dan konatif. Berdasarkan hasil penelitian diperoleh informasi bahwa siswa memberikan respon positif terhadap LKS berbasis inkuiri terbimbing dengan persentase pada dimensi kognitif sebesar $80 \%$, dimensi afektif sebesar 77\%, dan dimensi konatif sebesar 78\%. Secara keseluruhan siswa memberikan respon positif terhadap LKS berbasis inkuiri terbimbing dengan ratarata persentase skor sebesar $78 \%$.
\end{abstract}

Kata Kunci: LKS, inkuiri terbimbing, respon siswa.

\begin{abstract}
This research aims to determine the students' responses of guided inquiry-based student worksheet on human respiratory system subdivision. The method that was used in this research was descriptive with $11^{\text {th }}$ student grade of MIA 4 Senior High School Number 1 Pontianak on academic year 2016/2017 as the research subject with total 28 students. This research was a further research of development research that had been done by the researcher before. Student response questionnaire were used as the techniques of data collection. Closed questionnaire with Likert scale and has four valuation scale was used in this research. There was three dimension in this research, that is cognitive dimension, affective dimension, and conative dimension. As the research result, the students gave positive respond to guided inquiry-based student worksheet with percentage on cognitive dimension $80 \%$, affective dimension 77\%, and conative dimension $78 \%$. Overall, the students gave positive respond to guided inquiry-based student worksheet with percentage average $78 \%$.
\end{abstract}

Keywords: student worksheet, guided inquiry, students' responses.

\section{PENDAHULUAN}

Seiring perkembangan dan kemajuan dunia pendidikan, guru dituntut untuk selalu meningkatkan kualitas proses pembelajaran, menyelenggarakan kegiatan pembelajaran yang aktif, kreatif, efektif, dan menyenangkan sehingga 
keberhasilan belajar di dalam proses pembelajaran dapat tercapai. Salah satu faktor yang dapat menunjang keberhasilan proses pembelajaran adalah pemilihan bahan ajar. Prastowo (2014:138-140) mengatakan, bahan ajar dapat berupa buku pelajaran, modul, handout, Lembar Kerja Siswa (LKS), maket, bahan ajar audio, dan bahan ajar interaktif.

Berdasarkan wawancara yang dilakukan dengan lima orang guru SMA di Kota Pontianak, bahan ajar yang sering digunakan di sekolah selain buku pelajaran adalah LKS. LKS merupakan panduan siswa yang digunakan untuk melakukan kegiatan penyelidikan dan pemecahan masalah (Trianto, 2009: 148). Beberapa sekolah di Kota Pontianak telah menggunakan Kurikulum 2013. Penerapan LKS dapat mengaktifkan siswa ketika proses pembelajaran di kelas (Ranoptri, 2015: 1).

Penerapan pendekatan saintifik perlu didukung dengan penggunaan LKS berbasis penyelidikan (inquiry learning). Hal tersebut didukung oleh Permendikbud Nomor 22 pada Bab II (2016: 3) yang menyatakan bahwa untuk memperkuat pendekatan ilmiah (scientific), perlu diterapkan pembelajaran berbasis inkuiri. Jenis model pembelajaran inkuiri yang belum terbiasa belajar dengan discovery learning adalah inkuiri terbimbing, dikarenakan inkuiri terbimbing menyediakan lebih banyak arahan untuk para siswa yang belum siap untuk menyelesaikan masalah dengan inkuiri tanpa bantuan karena kurangnya pengalaman dan pengetahuan (Pratiwi, dkk., 2015: 33).

Penggunaan LKS dalam proses pembelajaran telah dilakukan oleh beberapa peneliti untuk mengetahui respon siswa terhadap penggunaannya. Penelitian Ana, dkk. (2010: 186) menunjukkan bahwa siswa memberikan respon positif terhadap LKS berbasis group investigation. Hasil penelitian Mayasari, dkk. (2015: 35) menunjukkan siswa memberikan respon sangat positif terhadap LKS berbasis karakter melalui pendekatan saintifik.

Berdasarkan observasi yang dilakukan di SMA Negeri 1 Pontianak, ratarata nilai ulangan harian siswa kelas XI MIA 1, XI MIA 2, XI MIA 3, dan XI MIA 4 materi Sistem Gerak, Sistem Peredaran Darah, Sistem Pencernaan Makanan, dan Sistem Pernapasan diketahui jika materi Sistem Pernapasan 
merupakan materi yang paling rendah rata-rata nilai ulangan hariannya jika dibandingkan dengan tiga materi sebelumnya. Hal tersebut dapat dilihat pada tabel berikut.

Tabel 1 Rata-Rata Nilai Ulangan Harian Siswa Kelas XI MIA 1, XI MIA 2, XI MIA 3, dan XI MIA 4 SMA Negeri 1 Pontianak

\begin{tabular}{lcccc}
\hline Materi & $\begin{array}{c}\text { Sistem } \\
\text { Gerak }\end{array}$ & $\begin{array}{c}\text { Sistem } \\
\text { Peredaran } \\
\text { Darah }\end{array}$ & $\begin{array}{c}\text { Sistem } \\
\text { Pencernaan } \\
\text { Makanan }\end{array}$ & $\begin{array}{c}\text { Sistem } \\
\text { Pernapasan }\end{array}$ \\
\hline XI MIA 1 & 91,80 & 88,34 & 88,00 & 84,51 \\
XI MIA 2 & 84,47 & 84,26 & 87,06 & 78,24 \\
XI MIA 3 & 82,97 & 82,00 & 86,39 & 75,19 \\
XI MIA 4 & 78,97 & 83,09 & 86,00 & 72,46 \\
\hline Rata-Rata & 84,55 & 84,42 & 86,86 & 77,60 \\
\hline
\end{tabular}

Hasil analisis ulangan harian Sistem Pernapasan menunjukkan jika ada beberapa siswa yang sulit membedakan antara mekanisme inspirasi dan ekspirasi. Hasil analisis ulangan harian kelas XI MIA 4 pada materi Sistem Pernapasan diuraikan sebagai berikut.

Soal nomor 8 pilihan ganda tentang mekanisme inspirasi dan ekspirasi, dari 35 siswa di kelas XI MIA 4 hanya 25,71\% siswa yang dapat menjawab dengan benar. Sedangkan pada soal nomor 12 pilihan ganda tentang pernapasan dada, dari 35 siswa di kelas XI MIA 4 hanya 37,14\% siswa yang dapat menjawab dengan benar. Selain sulit membedakan mekanisme inspirasi dan ekspirasi, siswa juga sulit membedakan antara bronkus dan bronkiolus. Pada soal isian, dari 35 orang siswa hanya $5,71 \%$ siswa yang dapat menjawab dengan skor yang maksimal (skor 2), $17,14 \%$ siswa menjawab skor 1 , dan $77,14 \%$ tidak dapat menjawab dengan tepat (skor 0). Berdasarkan uraian tersebut, peneliti tertarik untuk mengetahui respon siswa terhadap LKS berbasis inkuiri terbimbing pada submateri Sistem Pernapasan Manusia.

\section{METODE}

Metode penelitian yang digunakan adalah penelitian deskriptif. Penelitian yang dilakukan merupakan penelitian lanjutan dari penelitian pengembangan LKS 
berbasis inkuiri terbimbing pada submateri sistem pernapasan manusia kelas XI SMA Negeri 1 Pontianak yang telah dilakukan sebelumnya.

Subjek penelitian yang digunakan dalam penelitian adalah siswa kelas XI MIA 4 di SMA Negeri 1 Pontianak sebanyak 28 siswa. Pemilihan sekolah dan kelas dilakukan dengan teknik purposive sampling. SMA Negeri 1 Pontianak dipilih menjadi subjek penelitian karena memiliki alat dan bahan laboratorium yang lengkap untuk menunjang terlaksananya pembelajaran berbasis penyelidikan (inquiry learning). Kelas yang dipilih merupakan kelas dengan kemampuan kognitif yang paling rendah dengan tujuan agar siswa dapat memberikan respon yang baik terhadap LKS berbasis inkuiri terbimbing yang telah diberikan.

Instrumen yang digunakan dalam penelitian berupa angket. Angket yang digunakan adalah angket tertutup menggunakan skala Likert dengan empat skala penilaian (kriteria) yaitu SS (Sangat Setuju); S (Setuju); TS (Tidak Setuju); dan STS (Sangat Tidak Setuju). Angket yang digunakan terdiri atas 3 dimensi dengan 7 indikator dan 14 item pernyataan positif serta 12 item pernyataan negatif. Langkah-langkah pengolahan data angket, yakni menghitung frekuensi responden yang memilih SS, S, TS, dan STS pada tiap item pernyataan positif dan item pernyataan negatif. Kemudian menghitung skor total tiap-tiap item dengan kriteria yang dapat dilihat pada tabel berikut (Riduwan, 2015: 39).

Tabel 2 Kriteria Perhitungan Skor Angket

\begin{tabular}{ccc}
\hline Kategori & Pernyataan Positif & Pernyataan Negatif \\
\hline SS & 4 & 1 \\
S & 3 & 2 \\
TS & 2 & 3 \\
STS & 1 & 4 \\
\hline
\end{tabular}

Penentuan kriteria respon per-item dengan kriteria interpretasi yaitu angka $85 \% \leq \mathrm{RS}$ dinyatakan sangat positif, angka $70 \% \leq \mathrm{RS}<85 \%$ dinyatakan positif, angka $50 \% \leq \mathrm{RS}<70 \%$ dinyatakan kurang positif, dan angka $\mathrm{RS}<50 \%$ dinyatakan tidak positif dengan RS adalah respon siswa terhadap kriteria tertentu (Yamasari, 2010: 4). 


\section{HASIL DAN PEMBAHASAN}

Terdapat tiga dimensi respon yang akan dilihat setelah siswa mengisi angket yakni dimensi kognitif, afektif, dan konatif. Dimensi kognitif berkaitan erat dengan pengetahuan keterampilan dan informasi seseorang mengenai sesuatu (Amir, 2015: 16).

Tabel 3 Hasil Analisis Angket Respon Siswa

\begin{tabular}{|c|c|c|c|}
\hline \multirow{2}{*}{ Dimensi } & \multirow{2}{*}{ Indikator } & \multicolumn{2}{|c|}{ Respon Siswa } \\
\hline & & $\%$ Skor $(\mathrm{P})$ & Kategori Skor \\
\hline \multirow[t]{3}{*}{ Kognitif } & $\begin{array}{l}\text { Kemudahan dalam } \\
\text { memahami isi LKS }\end{array}$ & 74 & Positif \\
\hline & Kesesuaian tampilan LKS & 88 & Sangat Positif \\
\hline & $\begin{array}{l}\text { Kejelasan petunjuk belajar } \\
\text { dan informasi di dalam LKS }\end{array}$ & 79 & Positif \\
\hline \multicolumn{2}{|c|}{ Rata-rata respon pada dimensi kognitif } & 80 & Positif \\
\hline \multirow[t]{3}{*}{ Afektif } & Motivasi & 75 & Positif \\
\hline & Rasa ingin tahu & 78 & Positif \\
\hline & Kemenarikan & 78 & Positif \\
\hline \multicolumn{2}{|c|}{ Rata-rata respon pada dimensi afektif } & 77 & Positif \\
\hline Konatif & $\begin{array}{l}\text { Kecenderungan untuk melatih } \\
\text { tahapan inkuiri terbimbing }\end{array}$ & 78 & Positif \\
\hline \multicolumn{2}{|c|}{ Rata-rata respon pada dimensi konatif } & 78 & Positif \\
\hline \multicolumn{2}{|c|}{ Rata-rata respon secara keseluruhan } & 78 & Positif \\
\hline
\end{tabular}

Tabel 3 menunjukkan jika rata-rata respon siswa pada dimensi kognitif sebesar $80 \%$ yang berarti bahwa siswa memberikan respon positif terhadap LKS berbasis inkuiri terbimbing yang dikembangkan. Dimensi kognitif terdiri atas tiga indikator yakni kemudahan dalam memahami isi LKS, kesesuaian tampilan LKS, serta kejelasan petunjuk belajar dan informasi di dalam LKS.

Indikator pertama yakni kemudahan dalam memahami isi LKS. Jika dilihat pada Tabel 2, diperoleh informasi bahwa rata-rata indikator kemudahan dalam memahami isi LKS sebesar 74\% yang berarti siswa memberikan respon positif terhadap LKS berbasis inkuiri terbimbing. Hal tersebut berarti bahwa LKS berbasis inkuiri terbimbing mudah dipahami oleh siswa baik dari segi bahasa yang digunakan dan kemudahan dalam memahami konsep sistem pernapasan manusia. LKS berbasis inkuiri terbimbing disusun secara sistematis yang dimulai dengan siswa diminta untuk membaca petunjuk belajar yang berfungsi untuk 
mengarahkan siswa saat belajar menggunakan LKS, kemudian membaca tujuan yang akan dicapai, informasi pendukung di dalam LKS, membuat rumusan masalah dan hipotesis, melakukan pengamatan dan analisis data, dan yang terakhir membuat kesimpulan. Sehingga diharapkan siswa dapat mengerjakan LKS secara berurutan agar informasi yang didapat juga berurutan. Dengan demikian akan mempermudah pemahaman siswa dalam memahami materi yang sedang dipelajari. Hal tersebut sejalan dengan pendapat Sadjiati (2016: 44) yang menyatakan bahwa bahan ajar hendaknya disajikan secara sistematis, tidak meloncat-loncat alias runut. Kerunutan penyajian isi bahan ajar mempermudah siswa dalam belajar dan juga menuntun siswa untuk terbiasa berpikir runut.

Indikator kedua yakni kesesuaian tampilan LKS. Jika dilihat pada Tabel 3, diperoleh informasi bahwa rata-rata indikator kesesuaian tampilan LKS 88\% yang berarti siswa memberikan respon sangat positif terhadap LKS berbasis inkuiri terbimbing. Hal tersebut berarti bahwa tampilan LKS berbasis inkuiri terbimbing sangat baik dari segi penggunaan gambar/foto, tampilan warna yang digunakan, dan penggunaan jenis, ukuran, serta spasi sudah sesuai sehingga siswa dapat dengan mudah memahami materi pembelajaran yang ada di dalam LKS berbasis inkuiri terbimbing. Sejalan dengan pendapat Daryanto (2013: 14) yang menyatakan bahwa gambar hendaknya ditempatkan sedemikian rupa sehingga informasi mudah dimengerti oleh siswa dan hendaknya menggunakan bentuk dan ukuran huruf yang mudah dibaca.

Indikator ketiga yakni kejelasan petunjuk belajar dan informasi di dalam LKS. Jika dilihat pada Tabel 3, diperoleh informasi bahwa rata-rata indikator kejelasan petunjuk belajar dan informasi di dalam LKS sebesar $79 \%$ yang berarti siswa memberikan respon positif terhadap LKS berbasis inkuiri terbimbing. Hal tersebut berarti bahwa dengan adanya petunjuk belajar dan informasi yang jelas di dalam LKS berbasis inkuiri terbimbing mempermudah siswa dalam memahami materi Sistem Pernapasan Manusia dan mengerjakan LKS berbasis inkuiri terbimbing. Petunjuk belajar terdapat pada bagian paling atas halaman kedua LKS. Dengan adanya petunjuk belajar sebelum siswa mengerjakan LKS, dapat mengarahkan siswa di dalam proses pembelajaran menggunakan LKS berbasis 
inkuiri terbimbing. Hal tersebut sejalan dengan pendapat Prastowo (2014: 274) yang menyatakan bahwa komponen petunjuk belajar di dalam LKS berisi langkah bagi guru untuk menyampaikan bahan ajar kepada siswa dan langkah bagi siswa untuk mempelajari bahan ajar.

Dimensi afektif berkaitan dengan kondisi ketika siswa menghadapi sesuatu menggunakan emosi seperti perasaan, nilai, penghargaan, antusiasme, motivasi, dan sikap (Sitepu, 2015: 95). Tabel 3 menunjukkan jika rata-rata respon siswa pada dimensi afektif sebesar $77 \%$ yang berarti bahwa siswa memberikan respon positif terhadap LKS berbasis inkuiri terbimbing yang dikembangkan. Dimensi afektif terdiri atas tiga indikator yakni motivasi, rasa ingin tahu, dan kemenarikan.

Indikator pertama yakni motivasi. Motivasi adalah sesuatu yang menghidupkan, mengarahkan, dan mempertahankan perilaku (Ormrod, 2009: 58). Jika dilihat pada Tabel 3, diperoleh informasi bahwa rata-rata indikator motivasi sebesar $75 \%$ yang berarti siswa memberikan respon positif terhadap LKS berbasis inkuiri terbimbing. Hal tersebut berarti bahwa LKS berbasis inkuiri terbimbing dapat memotivasi siswa baik dalam proses pembelajaran maupun saat siswa berdiskusi di dalam kelompok.

Motivasi diberikan di dalam LKS berupa kalimat motivasi yang terdapat pada halaman pertama LKS dengan menghubungkan materi pembelajaran yang akan dipelajari dan manfaat yang akan diperoleh setelah proses pembelajaran selesai. Dengan adanya kalimat motivasi tersebut dapat memotivasi siswa di dalam proses pembelajaran maupun diskusi di dalam kelompok. Sadjiati (2016:47) menyatakan bahwa bahan ajar yang baik diharapkan dapat memotivasi siswa untuk membaca, mengerjakan tugas-tugasnya, serta menimbulkan rasa ingin tahu siswa untuk melakukan eksplorasi lebih lanjut tentang topik yang dipelajarinya. Hal serupa juga sejalan dengan pendapat Nurfauziyah, dkk. (2015: 238) bahwa pembentukan kelompok diskusi merupakan salah satu cara untuk membuat siswa aktif.

Indikator kedua yakni rasa ingin tahu. Jika dilihat pada Tabel 3, diperoleh informasi bahwa rata-rata indikator rasa ingin tahu sebesar $78 \%$ yang berarti siswa memberikan respon positif terhadap LKS berbasis inkuiri terbimbing. Hal 
tersebut berarti bahwa rasa ingin tahu siswa cukup besar saat menggunakan LKS berbasis inkuiri terbimbing di dalam proses pembelajaran. Di dalam LKS berbasis inkuiri terbimbing, terdapat beberapa pertanyaan yang berfungsi untuk menggali rasa ingin tahu siswa.

Keingintahuan siswa dicirikan dengan seringnya bertanya dan mencari tahu tentang sesuatu yang sedang dihadapi. Melalui rasa ingin tahu, siswa terdorong untuk mempelajari lebih lanjut tentang pengetahuan yang bermanfaat bagi dirinya maupun orang lain. Nurfauziyah, dkk. (2015:238) mengatakan bahwa pertanyaan guru merupakan salah satu cara untuk menumbuhkan rasa penasaran dan tantangan dalam diri siswa sehingga dapat menumbuhkan rasa ingin tahu siswa.

Indikator ketiga yakni kemenarikan. Jika dilihat pada Tabel 3, diperoleh informasi bahwa rata-rata indikator kemenarikan sebesar $78 \%$ yang berarti siswa memberikan respon positif terhadap LKS berbasis inkuiri terbimbing. Hal tersebut berarti bahwa LKS berbasis inkuiri terbimbing menarik untuk dibaca baik karena tata letak, kombinasi jenis huruf, dan ukuran huruf yang sesuai serta isi LKS berbasis inkuiri terbimbing. Hal tersebut sejalan dengan pendapat Nurdin dan Adriantoni (2016: 115) yang menyatakan LKS harus memiliki desain yang menarik.

Dimensi konatif berhubungan dengan perilaku nyata yang meliputi tindakan atau kebiasaan (Amir, 2015: 17). Dimensi konatif terdiri atas satu indikator, yakni kecenderungan untuk melatih tahapan inkuiri terbimbing. Jika dilihat pada Tabel 3, diperoleh informasi bahwa rata-rata indikator kecenderungan untuk melatih tahapan inkuiri terbimbing sebesar $78 \%$ yang berarti siswa memberikan respon positif terhadap LKS berbasis inkuiri terbimbing. Hal tersebut berarti bahwa LKS berbasis inkuiri terbimbing melatih siswa untuk membuat rumusan masalah, membuat hipotesis, mengumpulkan data, menganalisis data, dan membuat kesimpulan. Hal tersebut dikarenakan di dalam LKS berbasis inkuiri terbimbing, siswa diminta untuk membuat rumusan masalah berdasarkan tujuan pembelajaran yang telah ditetapkan.

Membuat hipotesis dari rumusan masalah yang telah dibuat, menganalisis, dan mengumpulkan data berdasarkan pengamatan maupun percobaan yang telah 
disusun di dalam LKS berbasis inkuiri terbimbing, dan membuat kesimpulan berdasarkan temuan yang telah didapat. Karena adanya latihan tersebut sehingga siswa terlatih untuk membuat rumusan masalah, membuat hipotesis, mengumpulkan data, menganalisis data, dan membuat kesimpulan. Nurfauziyah, dkk. (2015: 237) menyatakan bahwa hubungan antara stimulus dan respons akan semakin bertambah erat jika sering dilatih, dan akan semakin berkurang apabila jarang atau tidak pernah dilatih. Hal tersebut juga sejalan dengan penelitian yang dilakukan oleh Ariyani, dkk. (2015: 106) yang menyatakan bahwa keterampilan proses sains siswa kelas XI yang diajar menggunakan model inkuiri terbimbing meningkat sebesar $23,86 \%$.

\section{SIMPULAN}

Berdasarkan penelitian yang telah dilakukan, diketahui siswa memberikan respon positif terhadap LKS berbasis inkuiri terbimbing pada submateri Sistem Pernapasan Manusia dengan rerata persentase skor pada dimensi kognitif sebesar $80 \%$, dimensi afektif sebesar $77 \%$, dan dimensi konatif sebesar $78 \%$. Secara keseluruhan siswa memberikan respon positif terhadap LKS berbasis inkuiri terbimbing dengan rata-rata persentase skor sebesar $78 \%$.

\section{DAFTAR PUSTAKA}

Amir, T. 2015. Merancang Kuesioner: Konsep dan Panduan untuk Penelitian Sikap, Kepribadian, dan Perilaku. Jakarta: Prenadamedia Group.

Ana, N., Fitrihidajati, H., \& Susantini, E. 2010. Pengembangan Lembar Kerja Siswa (LKS) Berbasis Pembelajaran Kooperatif Group Investigation (GI) untuk Melatih Keterampilan Berpikir Kritis. Prosiding, Seminar Nasional Pendidikan Biologi. Solo: FKIP UNS.

Ariyani, M., Hamid, A., \& Leny. 2015. Meningkatkan Keterampilan Proses Sains dan Hasil Belajar Siswa pada Materi Koloid dengan Model Inkuiri Terbimbing (Guided Inquiry) pada Siswa Kelas XI IPA 1 SMA Negeri 11 Banjarmasin. Quantum, Jurnal Inovasi Pendidikan Sains. 6 (1): 98-107.

Daryanto. 2013. Menyusun Modul: Bahan Ajar untuk Persiapan Guru dalam Mengajar. Yogyakarta: Gava Media. 
Fatihudin, D. \& Holisin, I. 2012. Cara Praktis Memahami Penulisan: Karya Ilmiah, Artikel Ilmiah Dan Hasil Penelitian. Yogyakarta: UPP STIM YKPN.

Kementerian Pendidikan dan Kebudayaan Republik Indonesia. 2016. Peraturan Menteri Pendidikan dan Kebudayaan Republik Indonesia Nomor 22 Tahun 2016 Tentang Standar Proses Pendidikan Dasar dan Menengah. Jakarta: Kementerian Pendidikan dan Kebudayaan Republik Indonesia.

Mayasari, H., Syamsurizal, \& Maison. 2015. Pengembangan Lembar Kerja Siswa (LKS) Berbasis Karakter melalui Pendekatan Saintifik pada Materi Fluida Statik untuk Sekolah Menengah Atas. Edu-Sains. 4 (2): 30-36.

Nurdin, S. \& Adriantoni 2016. Kurikulum dan Pembelajaran. Depok: Rajagrafindo Persada.

Nurfauziyah, S., Marjono, \& Sugiharto, B. 2015. Penerapan Guided Inquiry untuk Meningkatkan Rasa Ingin Tahu Siswa pada Pembelajaran Biologi di Kelas XI IPA SMA Al Muayyad Surakarta Tahun Pelajaran 2014/2015. Prosiding, Seminar Nasional XII Pendidikan Biologi. Solo: FKIP UNS.

Ormrod, J. E. 2009. Psikologi Pendidikan: Membantu Siswa Tumbuh dan Berkembang. Jakarta: Erlangga.

Prastowo, A. 2014. Pengembangan Bahan Ajar Tematik. Jakarta: Kencana.

Pratiwi, D. M., Saputro, S. \& Nugroho, A. 2015. Pengembangan LKS Praktikum Berbasis Inkuiri Terbimbing pada Pokok Bahasan Larutan Penyangga Kelas XI IPA SMA. Jurnal Pendidikan Kimia (JPK). 4 (2): 32-37.

Ranoptri, D. 2015. Lembar Kerja Siswa (LKS) SD Media untuk Belajar Aktif. (Online, tersedia di http://www.kurikulumnasional.net/2015/12/lembarkerja-siswa-lks-sd-media-untuk.html, diakses tanggal 13 November 2016).

Riduwan. 2015. Dasar-Dasar Statistika. Bandung: Alfabeta.

Sitepu, B. P. 2015. Penulisan Buku Teks Pelajaran. Bandung: Remaja Rosdakarya.

Sugiyono. 2015. Metode Penelitian Kuantitatif, Kualitatif dan $R \& D$. Bandung: Alfabeta.

Trianto. 2009. Mendesain Model Pembelajaran Inovatif-Progresif. Jakarta: Kencana.

Yamasari, Y. 2010. Pengembangan Media Pembelajaran Matematika Berbasis ICT yang Berkualitas. Prosiding, Seminar Nasional X ITS. Surabaya: FMIPA ITS. 